\title{
Reassessment of Colombia's tropical glaciers retreat rates: are they bound to disappear during the 2010-2020 decade?
}

\author{
G. Poveda and K. Pineda \\ Graduate Programme in Water Resources, School of Geosciences and Environment, Universidad Nacional de Colombia, \\ Medellín, Colombia
}

Received: 19 May 2009 - Revised: 13 June 2009 - Accepted: 1 July 2009 - Published: 14 December 2009

\begin{abstract}
Clear-cut evidences of global environmental change in Colombia are discussed for diverse hydro-climatic records, and illustrated herein for increasing minimum temperature and decreasing annual maximum river flows records. As a consequence, eight tropical glaciers disappeared from the Colombian Andes during the 20th century, and the remaining six have experienced alarming retreat rates during the last decade. Here we report an updated estimation of retreat rates in the six remaining glacierized mountain ranges of Colombia for the period 1987-2007, using Landsat TM and TM+ imagery. Analyses are performed using detailed pre-processing, processing and post-processing satellite imagery techniques. Alarming retreat rates are confirmed in the studied glaciers, with an overall area shrinkage from $60 \mathrm{~km}^{2}$ in 2002 , to $55.4 \mathrm{~km}^{2}$ in 2003 , to less than $45 \mathrm{~km}^{2}$ in 2007. Assuming such linear loss rate $\left(\sim 3 \mathrm{~km}^{2}\right.$ per year), for the near and medium term, the total collapse of the Colombian glaciers can be foreseen by 2022, but diverse physical mechanisms discussed herein would exacerbate the shrinkage processes, thus prompting us to forecast a much earlier deadline by the late 2010-2020 decade, long before the 100 years foreseen by the 2007 IPCC Fourth Assessment Report. This forecast demands detailed monitoring studies of mass and energy balances. Our updated estimations of Colombia's glacier retreat rates posse serious challenges for highly valuable ecosystem services, including water supply of several large cities and hundreds of rural settlements along the Colombian Andes, but also for cheap and renewable hydropower generation which provides $80 \%$ of Colombia's demand. Also, the identified changes threaten the survivability of unique and fragile ecosystems like paramos and cloud forests, in turn contributing to exacerbate social unrest and
\end{abstract}

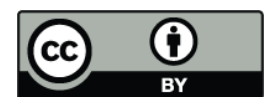

Correspondence to: G. Poveda (gpoveda@unal.edu.co) ongoing environmental problems in the tropical Andes which have been identified as the most critical hotspot for biodiversity on Earth. Colombia requires support from the global adaptation fund to develop research, and to design policies, strategies and tools to cope with these urgent social and environmental threats.

\section{Introduction}

\subsection{Evidences of hydro-climatic change in Colombia}

Diverse studies by Mesa et al. (1997), Pérez et al. (1998), Ochoa and Poveda (2008), and Poveda (2009) have performed analysis aimed at detecting signals of climatic change in lengthy series ( $\sim 40-45$ years) of monthly hydro-climatic records in Colombia, including changes in the mean and the variance, as well as trends and shifting levels. Their results confirmed the presence of statistically significant positive trends in average monthly minimum and mean temperature, as well as in relative humidity and pan evaporation throughout the country. In particular, strong positive trends on the order of $1^{\circ} \mathrm{C}$ in 20 years were identified for minimum temperature records. For instance, Fig. 2 shows the monthly average series of minimum temperature at the semi-rural airport of Pereira city during the period 1959-2007. Pereira is located around $1450 \mathrm{~m}$ a.s.l. on the western hills of Nevado del Ruiz and Santa Isabel glaciers (Fig. 1). Notice the strong positive trend in the mean but also the decreasing trend in the variance. Furthermore, monthly precipitation records exhibit mixed positive or negative trends with no clear spatial behavior, whereas most time series of river flows (annual averages and maxima) showed decreasing trends. Figure 3 taken from the study by Alvarez (2008) shows the spatial distribution of trends in time series of annual maxima river flows in Colombia. Notice that most series exhibit negative trends, which

Published by Copernicus Publications on behalf of the European Geosciences Union. 


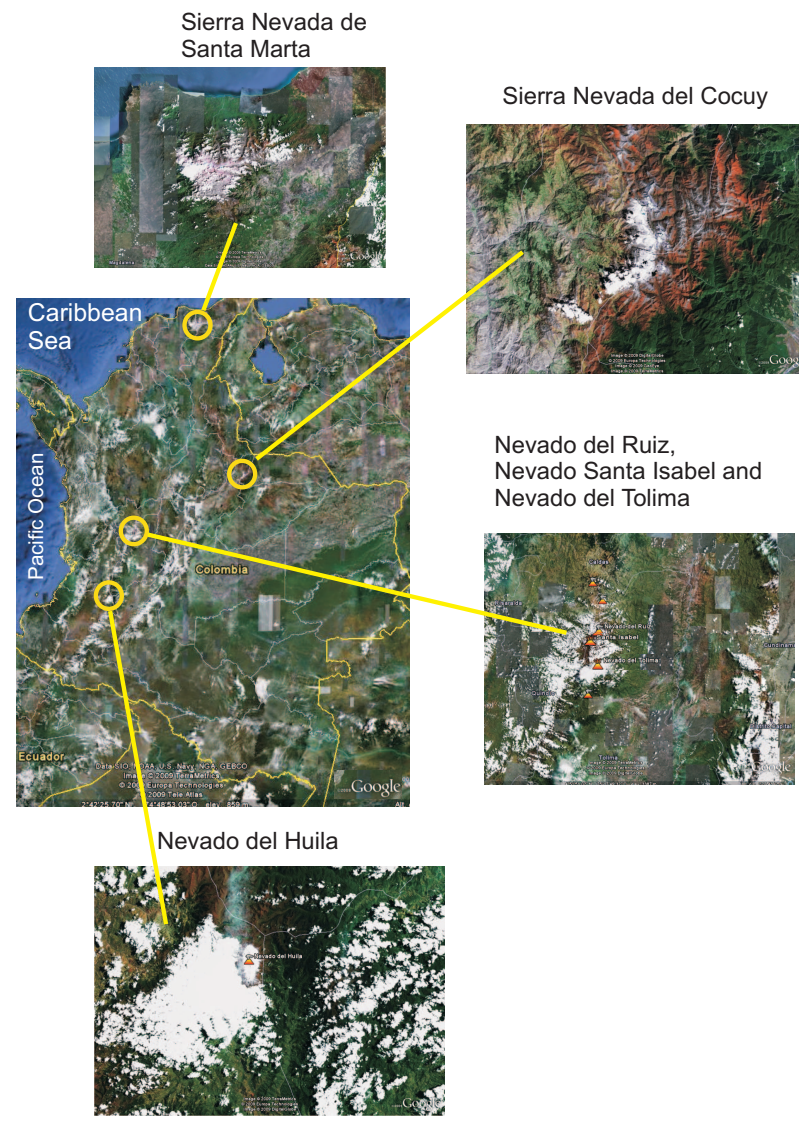

Fig. 1. Location of the six Colombian glacierized mountain ranges studied herein. The figure was made up using 12 June 2009 Google Earth imagery.

can be explained by the combined effects of deforestation, land use/land change, with global environmental change. It is impossible to disentangle the particular effect of either processes. Table 1 summarizes the number of hydro-climatic times series which were identified to exhibit positive, negative or no trends in the aforementioned studies.

\subsection{Colombian glaciers' retreat}

Tropical glaciers are unique and singular environments on Earth. The usually small size of inner tropical glaciers makes them highly sensitive to short timescales climate variability (Ceballos et al., 2006; Ramirez et al., 2001; Francou et al., 2003; Vuille et al., 2008), thereby constituting excellent proxies of regional and global climate change (Hastenrath and Kruss, 1992). The chapter on Latin America included in the 2007 Fourth Assessment Report of the Intergovernmental Panel on Climate Change (IPCC AR4) (Magrin et al., 2007), reported alarming and intensifying glacier retreat trends in the tropical Andes, reaching critical conditions in Bolivia, Peru, Colombia and Ecuador (see their Table 13.3), as well as in the works by Francou et al. (2000), Silverio and Jaquet

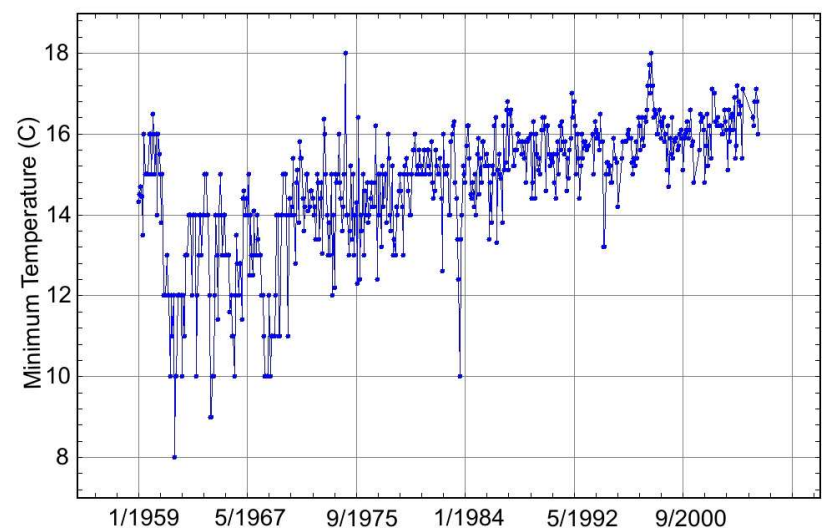

Fig. 2. Time series of average monthly minimum temperatures recorded at Pereira's country-side airport, located around $1450 \mathrm{~m}$ a.s.l. on the hills of the Ruiz and Santa Isabel glaciers.

Table 1. Distribution in the number of time series of diverse monthly average records of Colombia during 1960-1995, exhibiting statistically significant increasing, decreasing or no trends, according to the studies by Mesa et al. (1997), Pérez et al. (1998), Ochoa and Poveda (2008), and Poveda (2009).

\begin{tabular}{lrrrr}
\hline Variable & $\begin{array}{c}\text { Number of } \\
\text { time series }\end{array}$ & $\begin{array}{r}\text { Increasing } \\
\text { trend }\end{array}$ & $\begin{array}{r}\text { Decreasing } \\
\text { trend }\end{array}$ & $\begin{array}{r}\text { No } \\
\text { trend }\end{array}$ \\
\hline Minimum temperature & 51 & 36 & 7 & 8 \\
Mean temperature & 54 & 24 & 20 & 10 \\
Dew point & 37 & 24 & 6 & 7 \\
Vapor pressure & 33 & 17 & 6 & 10 \\
Tank evaporation & 25 & 11 & 10 & 4 \\
Precipitation & 150 & 23 & 7 & 120 \\
River discharges & 72 & 11 & 39 & 22 \\
\hline
\end{tabular}

(2005), and Soruco et al. (2009). In particular for Colombia, the 2007 IPCC AR4 identified an average glacier retreat rate of 10-15 m per year; and went on to forecast that under the current climate trends, Colombia's glaciers will disappear completely within the next 100 years.

The Colombian Andes and the singular Sierra Nevada de Santa Marta house the northernmost glaciers in tropical South America (Hoyos-Patiño, 1998). Such glaciers reached their maximum extent 35000 years ago, descending to 3000 $( \pm 200) \mathrm{m}$ a.s.l., and covering $17109 \mathrm{~km}^{2}$ (van der Hammen, 1985; IDEAM, 2000). The last glacier major growth occurred during the little ice age around 1600 and $1850 \mathrm{AD}$, reaching $374 \mathrm{~km}^{2}$ (Flórez, 2002), with minimum elevations between $4200-4400 \mathrm{~m}$ a.s.l. in the Central Andes and 4600 m a.s.l. in the Sierra Nevada de Santa Marta (Flórez, 1992). Many Colombian glaciers disappeared ever since, and many others have lost significant areal extent, amounting to $60 \%$ to $80 \%$ during the $1850-2000$ period (IDEAM, 2000). Eight tropical glaciers disappeared in Colombia during the 20th century, very likely from global and local warming and volcanic activity. Currently, just six glacierized mountain 


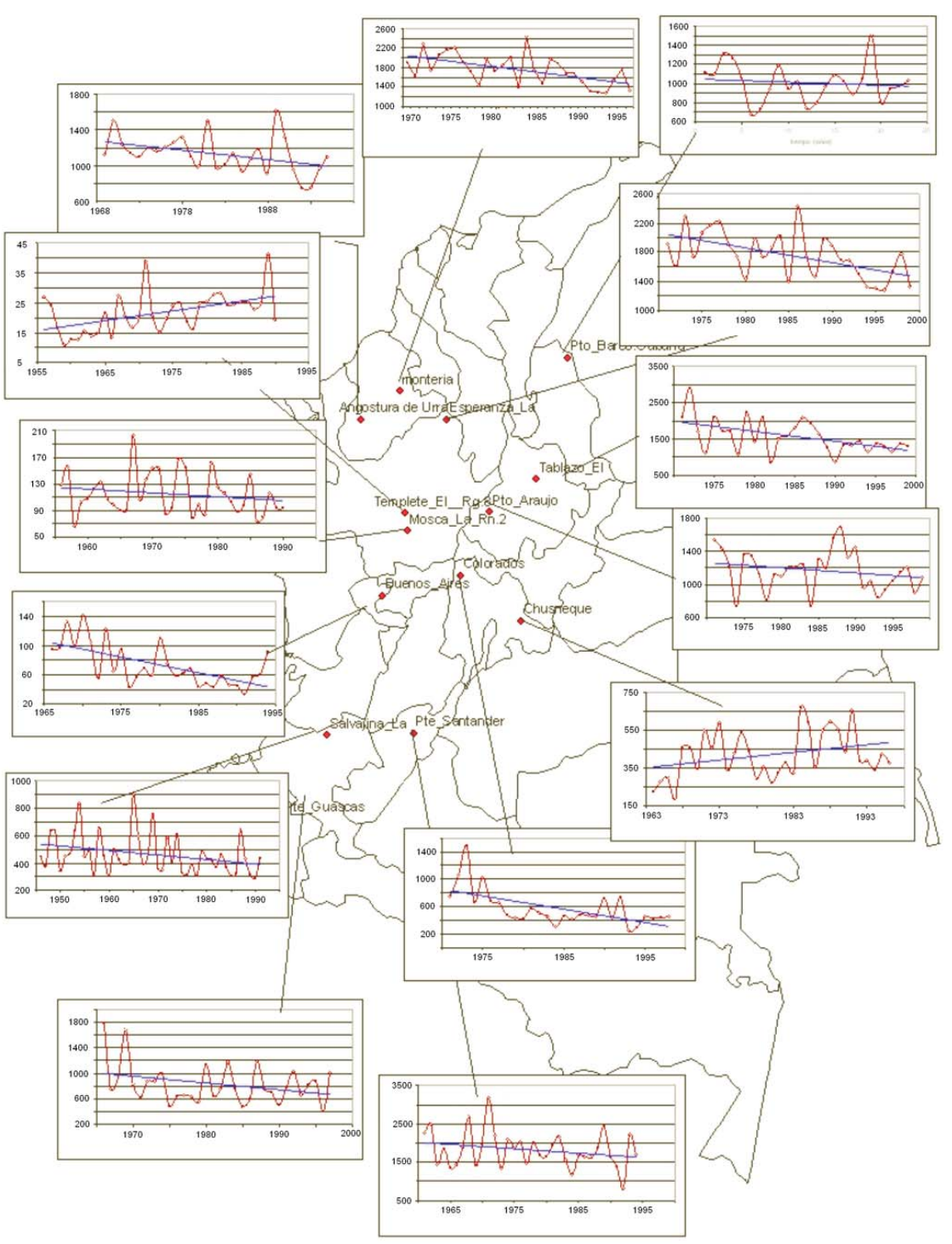

Fig. 3. Spatial distribution of time series of maximum annual river flows $\left(m^{3} s^{-1}\right)$ in Colombia. Notice that most time series exhibit statistically significant negative trends.

ranges remain in Colombia: Sierra Nevada de Santa Marta (5775 m a.s.1.), Sierra Nevada del Cocuy (5490 ma.s.1.), Volcán Nevado del Ruiz (5400 ma.s.l.), Volcán Nevado de Santa Isabel (5110 ma.s.1.), Volcán Nevado del Tolima (5280 m a.s.1.), and Volcán Nevado del Huila (5655 m a.s.1.), whose locations are shown in Fig. 1.

The study by Ceballos et al. (2006) found that in the past 50 years, Colombian glaciers lost on top of $50 \%$ of their areal extent, but glacier shrinkage has accelerated in the last 15 years, amounting to an extra $10 \%-50 \%$ glacier loss. Flórez (2002) reported for 2002 a glacierized area of $60 \mathrm{~km}^{2}$ in Colombia, while Ceballos et al. (2006) reported $55.4 \mathrm{~km}^{2}$ for 2003, with glacier termini found at $4700-4900 \mathrm{~m}$ a.s.l. They also found a relationship between fast glacier retreat and local, regional and global climate change, and indicated that the temperature rise of roughly $1^{\circ} \mathrm{C}$ in the last 30 years recorded at high-altitude meteorological stations exerts a primary control on glacier retreat. The study by Morris et al. (2006) found that in the 1950s, the total glacier area for Sierra Nevada de Santa Marta, Sierra Nevada del Cocuy, and Parque de los Nevados (Ruiz, Santa Isabel and Tolima) was $89.33 \mathrm{~km}^{2}$, and that by 2003 the total glacier area had been reduced to $45.77 \mathrm{~km}^{2}$. From the 1950 s to 2003 the calculated total ice loss in Colombia was $43.56 \mathrm{~km}^{2}$. The Sierra Nevada del Cocuy contributed $52 \%$ of the total ice lost, the Parque de los Nevados contributed $42 \%$ of this loss and the Sierra Nevada de Santa Marta contributed 6\%.

We aim to update (2007) estimations of the six glacierized mountain ranges remaining in Colombia and to re-assess their retreat rates using more recent satellite imagery. We 
Table 2. Characteristics of Landsat imagery used in this study. Parque de Nevados includes Ruiz, Santa Isabel, and Tolima glaciers.

\begin{tabular}{|c|c|c|c|c|c|c|}
\hline GLACIER & ID & Reference system WRS-2 & Date & Landsat series & Provider & Processing level \\
\hline Sierra Nevada de Santa Marta & $032-350$ & 2: $008 / 053$ & $30 / 12 / 1989$ & TM & EarthSat & Ortho, GeoCover \\
\hline Sierra Nevada de Santa Marta & 024-948 & 2: $008 / 053$ & $24 / 11 / 2002$ & ETM+ & USGS & L1G \\
\hline Sierra Nevada de Santa Marta & 080-095 & 2: $007 / 055$ & $06 / 01 / 2007$ & ETM+ & USGS & SLC-Off, L1G \\
\hline Sierra Nevada del Cocuy & $024-545$ & 2: $007 / 055$ & $26 / 12 / 1987$ & TM & USGS & L1G \\
\hline Sierra Nevada del Cocuy & $032-331$ & 2: $007 / 055$ & 02/09/1992 & TM & EarthSat & Ortho, GeoCover \\
\hline Sierra Nevada del Cocuy & 032-332 & 2: 007/056 & 02/09/1992 & TM & EarthSat & Ortho, GeoCover \\
\hline Sierra Nevada del Cocuy & $042-733$ & 2: $007 / 055$ & $13 / 12 / 2000$ & ETM+ & EarthSat & Ortho, GeoCover \\
\hline Sierra Nevada del Cocuy & $042-734$ & 2: 007/056 & $13 / 12 / 2000$ & ETM+ & EarthSat & Ortho, GeoCover \\
\hline Sierra Nevada del Cocuy & $081-410$ & 2: 007/055 & $31 / 01 / 2007$ & ETM+ & USGS & SLC-Off, L1G \\
\hline Sierra Nevada del Cocuy & $081-411$ & 2: $007 / 056$ & $31 / 01 / 2007$ & ETM+ & USGS & SLC-Off, L1G \\
\hline Parque de Nevados & 032-377 & 2: 009/058 & 07/08/1989 & TM & EarthSat & Ortho, GeoCover \\
\hline Parque de Nevados & $042-824$ & 2: 009/058 & $24 / 08 / 2001$ & ETM+ & EarthSat & Ortho, GeoCover \\
\hline Parque de Nevados & $073-238$ & 2: 009/058 & $24 / 02 / 2005$ & ETM+ & USGS & SLC-Off, L1G \\
\hline Huila & 032-377 & 2: 009/058 & 07/08/1989 & $\mathrm{TM}$ & EarthSat & Ortho, GeoCover \\
\hline Huila & $073-238$ & 2: 009/058 & $24 / 02 / 2005$ & ETM+ & USGS & SLC-Off, L1G \\
\hline
\end{tabular}

also aim to contrast our updated estimations with those given by Flórez (2002) for 2002 and by Ceballos et al. (2006) for 2003 , in order to diagnose the ongoing urgency and criticality of the problem.

\section{Data}

For estimation purposes we used Landsat satellite TM and $\mathrm{TM}+$ imagery of the visible and infrared bands at $28.5 \mathrm{~m}$ resolution for the the 1987-2007 period (Table 2). Source for the Landsat satellite imagery was the Global Land Cover Facility (GLCF). Elevation data from a Digital Elevation Model (DEM) of the United States Geological Survey (USGS), containing data gathered by the Shuttle Radar Topography Mission (SRTM) of NASA at $3 \operatorname{arcsec}(92 \mathrm{~m})$ resolution.

\section{Methodology}

Diverse pre-processing, processing and post-processing techniques were implemented on the satellite imagery, including:

- Pre-processing techniques refer to geo-referencing of imagery restoration, and also to correction of radiance values due to geometric distortion and atmospheric scattering (Bruce and Hilbert, 2004).

- Processing techniques were applied to improve imagery contrast by combining the following three images: (i) the Normalized Difference Snow Index (NDSI), (ii) the ratio between Landsat bands 4 and 5, and (iii) the Principal Component No. 2 of the red, green, and blue channels, (Sidjak and Wheate, 1999), as shown in Fig. 4. In addition to clearly differentiating snow from clouds, the NSDI reduces the influences of geometric and atmospheric effects (Gupta et al., 2005). Also, multispectral

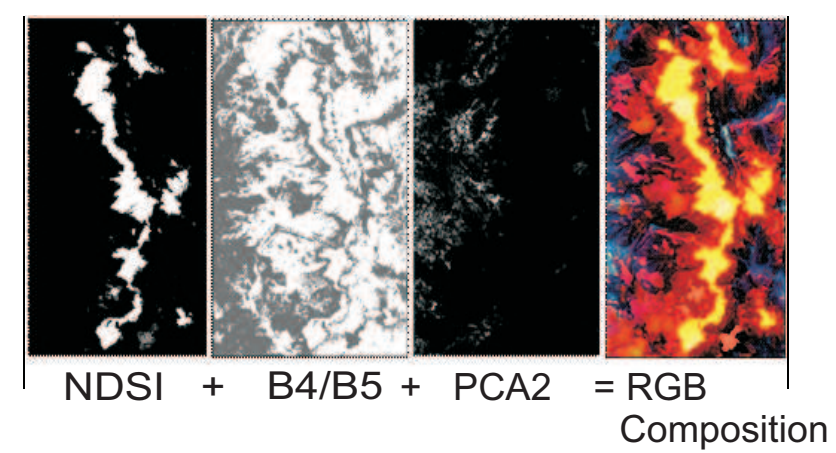

Fig. 4. Combination of images in the processing procedure. The Normalized Difference Snow Index (NDSI), the ratio between bands 4 and 5, and the Principal Component Analysis No. 2 in the red $(\mathrm{R})$, green $(\mathrm{G})$, and blue $(\mathrm{B})$, channels, are combined together to produce an improved RGB image.

imagery spatial segmentation techniques were applied, using a maximum likelihood method towards segmentation of images in a predefined number of classes using the spectral response of selected training parcels within the classes of interest.

- Post-processing techniques included coordinate system change, rasterization, polygon edition and areal estimation.

\section{Results and discussion}

1. Sierra Nevada de Santa Marta. Estimates of glacierized area are $10.14 \mathrm{~km}^{2}$ in $1989,7.33 \mathrm{~km}^{2}$ in 2002 , and $5.95 \mathrm{~km}^{2}$ in 2007 . It lost $41 \%$ of its area 
( a )

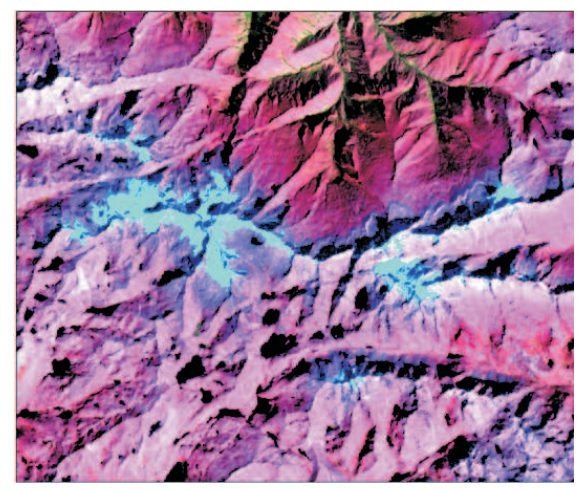

( c )

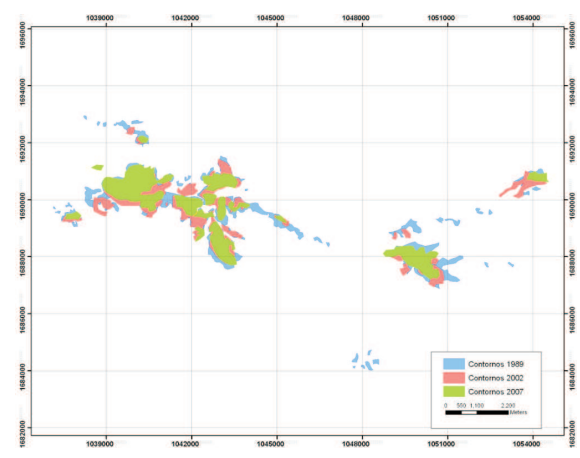

( b )

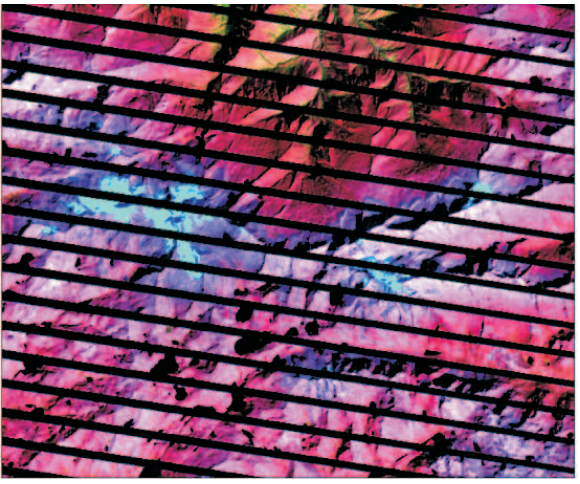

$(\mathrm{d})$

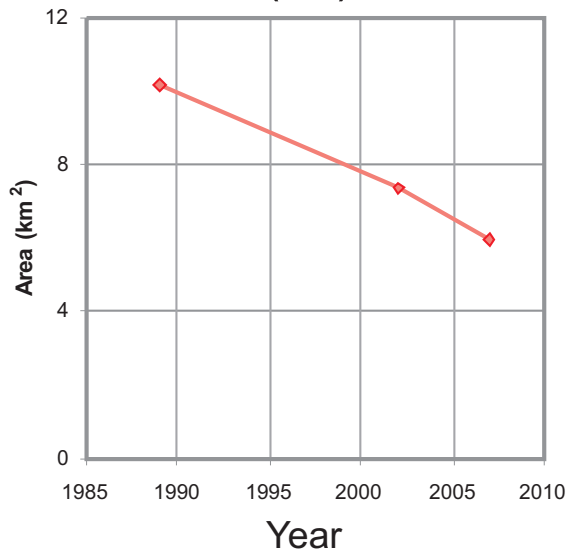

Fig. 5. Landsat images of Sierra Nevada de Santa Marta glacier in (a) December 1989, and (b) January 2007. (c) Glacier countours in 1989 (blue), 2002 (pink), and 2007 (green). (d) Time evolution of glacier areal extent: $10.14 \mathrm{~km}^{2}(1989), 7.33 \mathrm{~km}^{2}(2002)$, and 5.95 km² (2007).

during 1989-2007, with an average retreat rate of $232611 \mathrm{~m}^{2}$ year $^{-1}$, although from the year 2000 it increased to $275000 \mathrm{~m}^{2}$ year $^{-1}$. The high spatial fragmentation and the geographical and environmental characteristics make this glacier most vulnerable to global warming. It is known that scale and edge effects become effective for tropical glaciers retreat when they reach a critical size (Ceballos et al., 2006; Francou et al., 2003). Figure 5 shows the time evolution of the glacier areal extent.

2. Sierra Nevada del Cocuy. Estimates of glacierized area are $28.66 \mathrm{~km}^{2}$ in $1989,22.9 \mathrm{~km}^{2}$ in 2000 , and $17.00 \mathrm{~km}^{2}$ in 2007 . It lost $41 \%$ of its glacier area during 1989-2007, with an average annual retreat rate of $648000 \mathrm{~m}^{2}$ year $^{-1}$, although from the year 2000 it increased to $843000 \mathrm{~m}^{2}$ year $^{-1}$. This glacier exhibits the largest of net retreat rates among the studied herein, including that for the 2000-2007 period. See Fig. 6.
3. Nevado del Ruiz volcano. Estimates of glacierized area are $14.06 \mathrm{~km}^{2}$ in 1989 , and $8.66 \mathrm{~km}^{2}$ in 2004 . It lost $38 \%$ of its glacier area during the 19892004 period, with an average annual retreat rate of $360000 \mathrm{~m}^{2}$ year $^{-1}$. It is worth noting that Nevado del Ruiz currently exhibits low-level volcanic activity, which enhances the warming process and glacier loss.

4. Nevado de Santa Isabel volcano. Estimates of glacierized area are $6.50 \mathrm{~km}^{2}$ in $1989,5.19 \mathrm{~km}^{2}$ in 1991 , and $3.28 \mathrm{~km}^{2}$ in 2004 . It lost $49 \%$ of its glacier area during the 1989-2004 period, with an average annual retreat rate of $214000 \mathrm{~m}^{2}$ year $^{-1}$. Climatic variables are indeed related to this glacier retreat (Euscátegui and Ceballos, 2002), which does not show any sign of volcanic activity.

5. Nevado del Tolima volcano. Estimates of glacierized area are $1.27 \mathrm{~km}^{2}$ in 1991 , and $0.96 \mathrm{~km}^{2}$ in 2004 . It lost $24 \%$ of its glacier area during the 1991-2004 period, with an average annual retreat rate of $24000 \mathrm{~m}^{2}$ year $^{-1}$ 
( a )

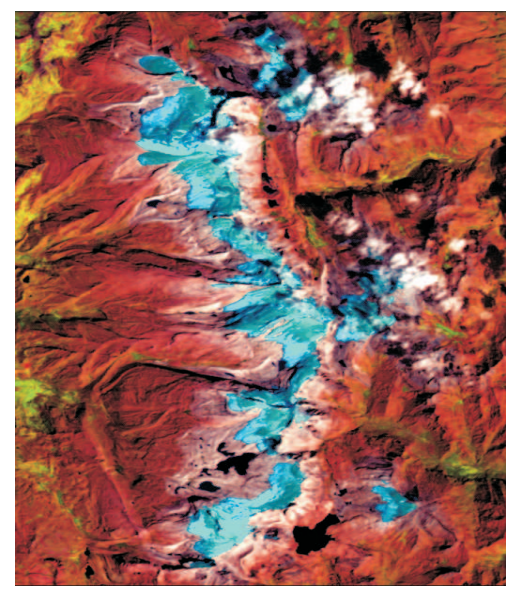

(c)

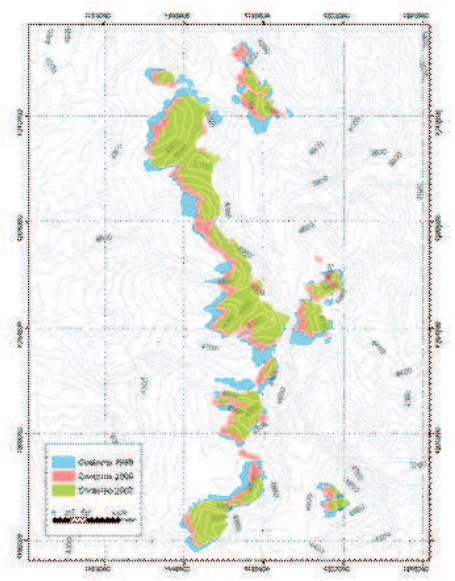

( b )

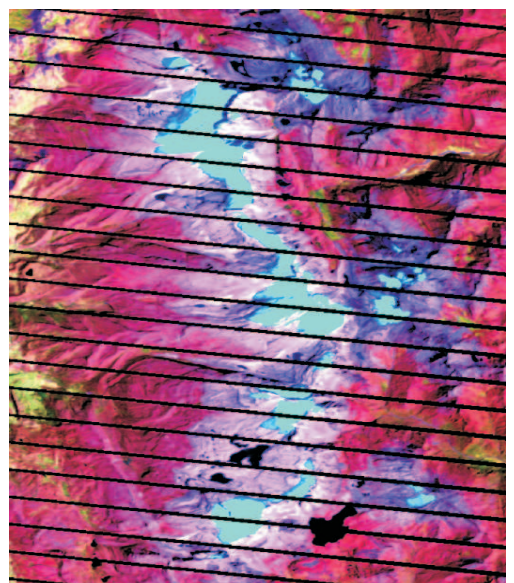

(d)

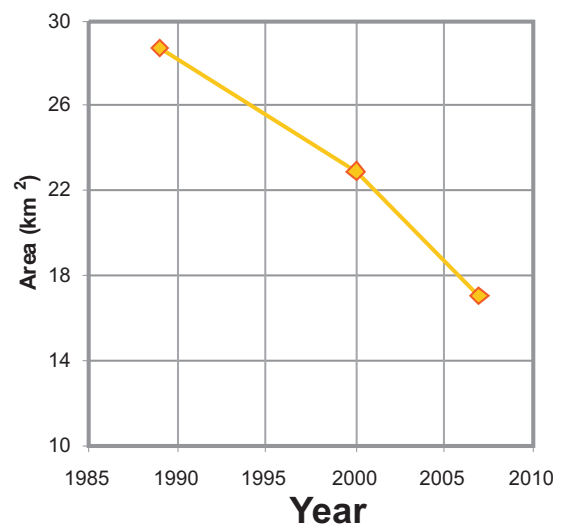

Fig. 6. Landsat images of the Sierra Nevada del Cocuy in (a) December 1987, and (b) January 2007. (c) Glacier countours in 1989 (blue), 2000 (pink), and 2007 (green). (d) Time evolution of glacier areal extent: $28.66 \mathrm{~km}^{2}$ (1989), $22.9 \mathrm{~km}^{2}$ (2000), and 17.00 km² (2007).

6. Nevado del Huila volcano. Estimates of glacierized area are $18.39 \mathrm{~km}^{2}$ in $1989,13.84 \mathrm{~km}^{2}$ in 2001 , and $7.94 \mathrm{~km}^{2}$ in 2005. It lost $56 \%$ of its glacier area during the 19892005 period, with an average annual retreat rate of $653000 \mathrm{~m}^{2}$ year $^{-1}$. Among the studied glaciers, Huila showed the largest areal extent shrinkage, and since 2006 it has been showing signs of volcanic activity, which can speed up the glacier shrinkage process. See Fig. 7.

A summary of the newly estimated retreat rates and remaining glacier areas in Colombia is shown in Table 3. Our estimates are subject to several uncertainties owing to: (i) imagery restoration processes, (ii) presence of shadows associated with clouds and topography, (iii) changes in coordinate reference system, (iv) processes of conversion into raster images, and ( $\mathrm{v}$ ) mixing of information from image borders. This latter procedure is highly sensitive to the spatial and spectral resolution of satellite imagery, but also to spatial segmentation procedures (Fernandez et al., 2004; Oltof and Latifovich, 2004).

Our estimates indicate that 2007 Colombia's total glacierized area amounted to less than $45 \mathrm{~km}^{2}$. Also glacier termini is now found at around $4800 \mathrm{~m}$ a.s.l. The most likely cause of the identified glacier retreat rates is the increase in average minimum and mean temperatures, as evidenced in Fig. 2, which confirms those results found by Mesa et al. (1997), Pérez et al. (1998), Ochoa and Poveda (2008), and Poveda (2009). It is much less likely that glaciers' retreat have been caused by a generalized decrease in precipitation (drying) since no clear-cut regional or national trends have been found in rainfall records, though river discharges of most important river basins are showing decreasing trends, as indicated in the last two rows of Table 1, as well as in Fig. 3. 
Table 3. Summary of identified Colombia's estimated glaciers retreat rates and remaining areas.

\begin{tabular}{|c|c|c|c|c|}
\hline GLACIER & Period & $\begin{array}{r}\text { Area loss } \\
(\%)\end{array}$ & $\begin{array}{l}\text { Mean retreat rate } \\
\qquad\left[\mathrm{m}^{2} \text { year }^{-1}\right]\end{array}$ & $\begin{array}{l}\text { Remaining } \\
\text { Area }\left[\mathrm{km}^{2}\right]\end{array}$ \\
\hline Sierra Nevada de Santa Marta & 1989-2007 & 41 & 275000 & 6 \\
\hline Sierra Nevada del Cocuy & 1989-2007 & 40 & 843000 & 17 \\
\hline Nevado del Ruiz & 1989-2004 & 38 & 360000 & 8 \\
\hline Nevado de Santa Isabel & 1989-2004 & 49 & 214000 & 4 \\
\hline Nevado del Tolima & 1991-2004 & 49 & 24000 & 2 \\
\hline Nevado del Huila & 1989-2005 & 56 & 653000 & 8 \\
\hline
\end{tabular}

\section{(a)}

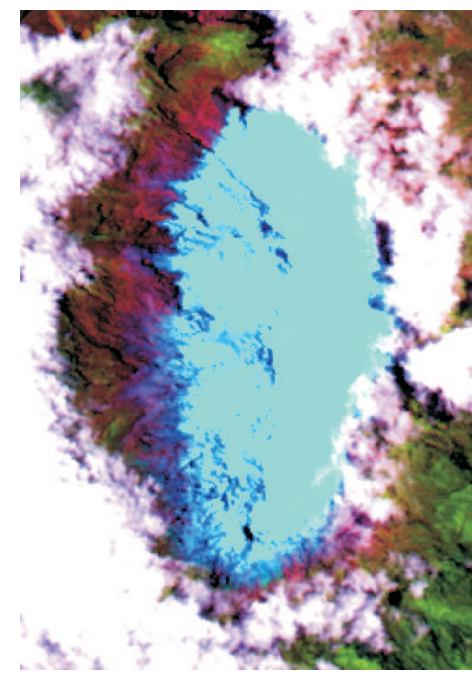

(c)

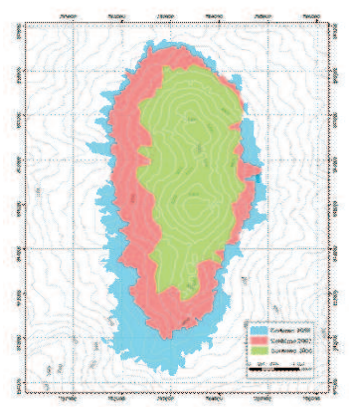

(b)

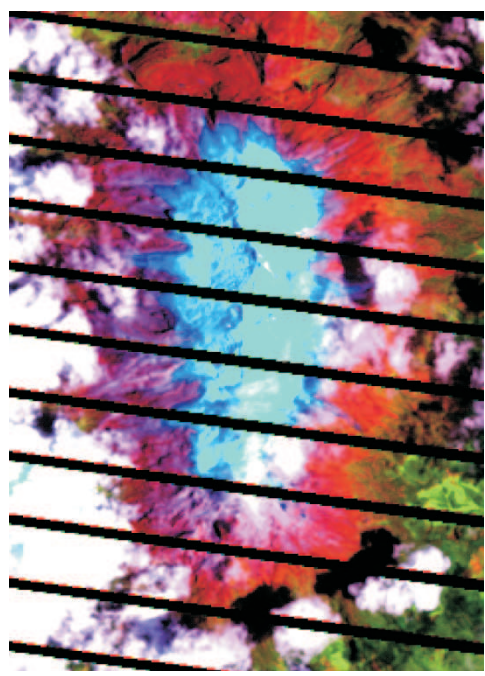

(d)

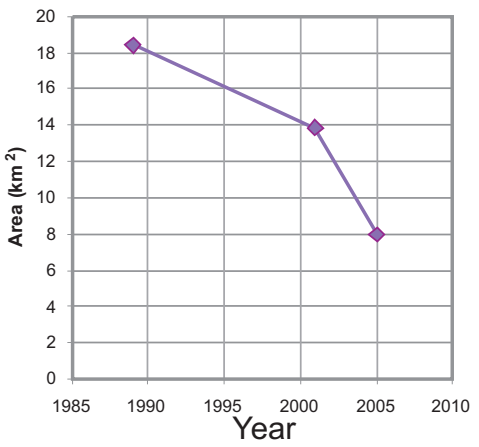

Fig. 7. Landsat images of Nevado del Huila in (a) August 1989, and (b) December 2005. (c) Glacier countours in 1989 (blue), 2001 (pink), and 2005 (green). (d) Time evolution of glacier areal extent: $18.39 \mathrm{~km}^{2}$ (1989), $13.84 \mathrm{~km}^{2}$ (2001), and $7.94 \mathrm{~km}^{2}(2005)$.

In absence of detailed mass-balance studies do date in Colombia (Ceballos et al., 2006), and considering our updated estimates, the reported $60 \mathrm{~km}^{2}$ for 2002 (Flórez, 2002), and $55.4 \mathrm{~km}^{2}$ for 2003 (Ceballos et al., 2006), an average glacier retreat for Colombia can be estimated roughly as $3.0 \mathrm{~km}^{2}$ year $^{-1}$. Assuming such linear trend for the near future, we can conjecture that Colombian glaciers will disappear around the year 2022. Nevertheless, such deadline seems to be an extremely optimistic scenario due to the following facts:

1. Our latter estimates for Nevado del Ruiz, Santa Isabel and Tolima glaciers correspond to 2004, and they have continued to shrink ever since (J. Ceballos, and B. Francou, personal communication, 2009). 
2. We have to bear in mind that positive feedbacks occur between glacier retreat and precipitation phase (liquid/solid) and albedo, considering the maximum glacier height. Such feedbacks determine the ELA elevation (around $5100 \mathrm{~m}$ ) is close to the maximum elevation of these glaciers. In this case, most glaciers are in an out of equilibrium state (for instance Santa Isabel), and their extinction time depends on the maximum ice cap width and the annual ablation rate (B. Francou, personal communication, 2009).

3. We also have to bear in mind the aforementioned scale and edge effects becoming effective for tropical glaciers retreat when they reach a critical size (Ceballos et al., 2006; Francou et al., 2003).

4. The estimated $2.6 \mathrm{~km}^{2}$ year ${ }^{-1}$ retreat rate constitute an average long-term value, but local retreat rates may differ due to differences in topography, microclimate features such as maximum temperature, relative humidity and solar radiation (Kaser, 1999; Euscátegui, 2002, 2003), and fragmentation degree among glaciers.

5. A major concern related to local and global warming is the change of solid precipitation (snow) for liquid water, thus contributing to decrease the net glacier solid mass balance.

6. Glacier loss would accelerate should global warming is associated with more frequent El Niño events. Guilyardi (2006) showed that among those climate change models that best reproduced the diversity of the observed El Niño/Southern Oscillation (ENSO) events, there was a significant trend towards increased El Niño amplitude in high $\mathrm{CO}_{2}$ scenarios (Guilyardi et al., 2009). Although this issue is still under discussion, it is well documented that El Niño is associated with positive anomalies in minimum and average air temperatures, but also with negative precipitation anomalies over most of Colombia (Poveda and Mesa, 1997; Waylen and Poveda, 2001; Poveda et al., 2001, 2005, 2006), which are also evidenced in glacier areas (Euscátegui, 2002; Ceballos et al., 2006). It is also known that La Niña is associated with negative anomalies in air temperatures and positive anomalies in rainfall (Poveda et al., 2001), both of which would tend to recover glacier masses, but the higher frequency of $\mathrm{El}$ Niño (3-4 years) with respect to La Niña (5-6 years) would contribute to speed up glaciers'net losses.

7. An extremely important factor of tropical glacier mass balance is the amplitude of the diurnal cycle of temperatures, which in Colombia is showing long-term signs of intensification as a result from global and local warming, but also during during El Niño events (Poveda et al., 2005). Also, these trends point out to an acceleration of glacier shrinkage rates.
8. At any rate, these statistical extrapolations need to be confirmed with an thorough and comprehensive monitoring study of mass and energy budgets on these Colombian tropical glaciers.

In view of these, it is very likely that our estimated 2024 deadline might be anticipated to the later years of the 20102020 decade, with some regional differences in timing and severity of environmental and water resources implications. The likely disappearance of Colombian glaciers posses an enormous threat to the survival of paramos, endemic unique ecosystems of the tropical Andes (Cuatrecasas, 1968; Balslev and Luteyn, 1992; Mora-Osejo and Sturm, 1995; Pabón and Hurtado, 2002; Hofstede et al., 2003), with serious ecological implications for the region, as yet identified as the most critical hotspot for biodiversity in the world (Myers et al., 2000). Paramos are water sources for many small towns and villages along the Andes (including Bogotá), as is the case in the glaciers of Ecuador and Peru (Hastenrath and Ames, 1995; Vuille et al., 2008), but also for very cheap, clean and renewable hydropower generation. At any rate, these updated estimates allow us to forecast the deadline of Colombia's glaciers long before the next 100 years predicted by the 2007 IPCC Fourth Assessment Report (Magrin et al., 2007). Besides research and monitoring programs to quantify the local surface energy balance, adaptation plans and activities need to be urgently implemented in Colombia to face the threats arising from the glaciers' retreat and disappearance.

\section{Conclusions}

We have updated the retreat rates estimates of the six remaining tropical glacierized mountain ranges of Colombia for the period 1987-2007, using Landsat TM and TM+ imagery. Analysis was performed using detailed pre-processing, processing and post-processing techniques. Estimates for all glaciers studied herein show that shrinkage rates have speed up since 2000, and that the glacierized area decreased from $60 \mathrm{~km}^{2}$ in 2002 (Flórez, 2002), to $55.4 \mathrm{~km}^{2}$ in 2003 (Ceballos et al., 2006), to less than $45 \mathrm{~km}^{2}$ in 2007 , meaning an average retreat rate of $3.0 \mathrm{~km}^{2}$ year ${ }^{-1}$, albeit with some regional differences in timing and strength of retreat. At such pace all Colombian glaciers will disappear around the year 2022, although many other factors are present that tend to speed up the shrinking processes. Therefore, we conjecture the deadline of Colombian glaciers some time during the late part of the 2010-2020 decade, long before the 100 years deadline mentioned by the 2007 IPCC AR4. In any case, these Colombian tropical glaciers deserves the urgent implementation of thorough and comprehensive monitoring programme to study their mass and energy balances. As such, the Colombian tropical glaciers are environments on the verge of extinction, with enormous implications for water resources planning and management and ecosystems' 
survival. Colombia requires to get funding from the global adaptation fund to design the policies, strategies and tools to cope with these urgent social and environmental threats.

Acknowledgements. We thank COLCIENCIAS for supporting the GRECIA Research Programme, and IDEAM for providing hydroclimatic data as part of the same Programme. Financial support from DIME is also acknowledged. Diana M. Alvarez contributed Fig. 3. We are grateful to B. Francou, S. Hastenrath, and the anonymous reviewers for their valuable comments and suggestions to improve the manuscript. Source for the Landsat satellite imagery was the Global Land Cover Facility (GLCF), www.landcover.org. We also thank Google Earth, Europa Technologies, Tele Atlas, and DMapas for making available images included in Fig. 1.

Edited by: R. Garraud

Reviewed by: two anonymous referees

\section{References}

Alvarez, D. M.: Nuevos enfoques para la estimación de caudales extremos en Colombia, M.Sc. Thesis, Graduate Programme in Water Resources, Universidad Nacional de Colombia at Medellin, 2008.

Balslev, H. and Luteyn, J. (Eds.): Páramo: An Andean Ecosysten under Human Influence. Academic Press, London, 1992.

Bruce, C. and Hilbert, D.: Preprocessing methodology for application to Landsat TM/TM+ imagery of the wet tropics. Rainforest RCR, Tropical Forest Research Centre and SCIRO, Cooperative Research Centre for Tropical Rainforest Ecology and Management, Australia, 2004.

Ceballos, J. L., Euscátegui, C., Ramirez, J., Cañon, M., Huggel, C., Wilfred, H., and Machguth, H.: Fast shrinkage of tropical glaciers in Colombia, Ann. Glaciol., 43, 194-201, 2006.

Cuatrecasas, J.: Páramo Vegetation and its Life Forms, in: Geoecology of Mountainous Regions of Tropical America, edited by: Troll, C., Coll. Geogr., Bonn, 9, 163-186, 1968.

Euscátegui, C.: Incidencia de las variaciones del brillo solar en la dinámica glaciar del volcán nevado Santa Isabel, Meteorol. Colomb., 6, 1-11, 2002.

Euscátegui, C.: Estado de los glaciares en Colombia y análisis de la dinámica glaciar en el Parque Los Nevados, asociada al cambio climático global, M.Sc. Thesis, Universidad Nacional de Colombia, Bogotá, 2003.

Euscátegui, C. and Ceballos, J. L.: Retroceso glaciar en el volcán Nevado de Santa Isabel y su relación con el comportamiento climático (Cordillera Central Colombia), Memorias del Congreso Mundial de Páramos, Bogotá, 144-150, online available at: http://www.lablaa.org/blaavirtual/geografia/congresoparamo/ cambio-climatico.htm, 2002.

Fernandes, R., Fraser, R., Latifovic, R., Cihlar, J., Beaubien, J., and $\mathrm{Du}, \mathrm{Y} .:$ Approaches to fractional land cover and continuous field mapping: A comparative assessment over the BOREAS study region, Remote Sens. Environ., 89, 234-251, 2004.

Flórez, A.: Los nevados de Colombia: Glaciales y glaciaciones, Anál. Geogr., 22, 15-55, 1992.

Flórez, A.: Movilidad altitudinal de páramos y glaciares en los Andes Colombianos, Memorias del Congreso Mundial de Páramos, Bogotá, 80-90, online available at: http://www.lablaa.org/blaavirtual/geografia/congresoparamo/ cambio-climatico.htm, 2002.

Francou B., Ramirez E., Cáceres B., and Mendoza J.: Glacier evolution in the tropical Andes during the last decades of the 20th century: Chacaltaya, Bolivia, and Antizana, Ecuador, AMBIO, 29(7), 416-422, 2000.

Francou, B., Vuille, M., Wagnon, P., Mendoza, J., and Sicart, J. E.: Tropical climate change recorded by a glacier in the central Andes during the last decades of the twentieth century: Chacaltaya, Bolivia, 168S., J. Geophys. Res., 108(D5), 4154, doi:10.1029/2002JD002959, 2003.

Guilyardi, E.: El Niño-mean state-seasonal cycle interactions in a multi-model ensemble, Clim. Dynam., 26, 329-348, 2006.

Guilyardi, E., Wittenberg, A., Fedorov, A., Collins, M., Wang, C., Capotondi, A., van Oldenborgh, G. J., and Stockdale, T.: Understanding El Niño in ocean-atmosphere general circulation models: Progress and challenges, B. Am. Meteorol. Soc., 90, 325340, doi:10.1175/2008BAMS2387.1, 2009.

Gupta, R. P., Haritashya, U. K., and Sing, P.: Mapping dry/wet snow cover in the Indian Himalayas using IRS multispectral imagery, Remote Sens. Environ., 97, 458-469, 2005.

Hastenrath, S. and Ames, A.: Diagnosing the imbalance of Yanamarey Glacier in the Cordillera Blanca of Peru, J. Geophys. Res., 100(D3), 5105-5112, 1995.

Hastenrath, S. and Kruss, P. D.: The dramatic retreat of Mount Kenya's glaciers between 1963 and 1987: Greenhouse forcing, Ann. Glaciol., 16, 127-133, 1992.

Hofstede, R., Segarra, P., and Mena Vásconez, P. (Eds.): Los Páramos del Mundo. Proyecto Atlas Mundial de los Páramos, Global Peatland Initiative/NC-IUCN/EcoCiencia, Quito, 2003.

Hoyos-Patiño, F.: Glaciers of Colombia, in: Satellite Image Atlas of Glaciers of the World South America, edited by: Williams Jr., R. S. and Ferrigno J. G., USGS Professional Paper 1386-I, United States Government Printing Office, Washington DC, 1130, 1998.

IDEAM: Los glaciares Colombianos, expresión del cambio climatico global, Bogotá, 19 p., online available at: http://www. ideam.gov.co/publica/glaciares/glaciares.pdf, 2000.

Kaser, G.: A review of the modern fluctuations of tropical glaciers, Global Planet. Change, 22(1-4), 93-103, 1999.

Magrin, G., Gay García, C., Cruz Choque, D., Giménez, J. C., Moreno, A. R., Nagy, G. J., Nobre, C., and Villamizar, A.: Latin America. Climate Change 2007: Impacts, Adaptation and Vulnerability. Contribution of Working Group II to the Fourth Assessment Report of the Intergovernmental Panel on Climate Change, edited by: Parry, M. L., Canziani, O. F., Palutikof, J. P., van der Linden P. J., and Hanson, C. E., Cambridge University Press, Cambridge, UK, 581-615, 2007.

Mesa, O. J., Poveda, G., and Carvajal, L. F.: Introducción al Clima de Colombia, Universidad Nacional de Colombia Press, Bogotá, 390 pp., 1997.

Mora-Osejo, L. E. and Sturm H. (Eds.): Estudios ecológicos del páramo y del bosque altoandino cordillera oriental de Colombia, Academia de Ciencias Exactas Físicas y Naturales, Jorge Alvarez Lleras Collection, (6)715, 1995.

Morris, J. N., Poole, A. J., and Klein, A. G.: Retreat of tropical glaciers in Colombia and Venezuela from 1984 to 2004 as measured from ASTER and Landsat images, In: Proc. 63rd Eastern Snow Conference, Newark, Delaware, USA, 181-191, 2006. 
Myers, N., Mittermeier, R. A., Mittermeier, C. G., daFonseca, G. A. B., and Kent, J.: Biodiversity hotspots for conservation priorities, Nature, 403, 853-858, 2000.

Ochoa, A. and Poveda, G.: Distribución espacial de señales de cambio climático en Colombia, Proc. XXIII Latin American Hydraulics Meeting, IAHS, Cartagena, Colombia, Septembrer 2008.

Oltof, I. and Latifovic, R.: Accuracy assessment using sub-pixel fractional error matrices of global land cover products derived from satellite data, Remote Sens. Environ., 90, 153-165, 2004.

Pabón, J. D. and Hurtado, G.: La variabilidad y el cambio climático y su efecto en los biomas de páramo, Memorias del Congreso Mundial de Páramos, Bogotá, 98-103, online available at: http://www.lablaa.org/blaavirtual/geografia/congresoparamo/ cambio-climatico.htm, 2002.

Pérez, C. A., Poveda, G., Mesa, O. J., Carvajal, L. F., and Ochoa, A.: Evidences of climate change in Colombia: Trends, phase and amplitude shifts of the annual and semi-annual cycles, 2nd International Conference on Climate and Water, Helsinki, 17-20 August, 1046-1054, 1998.

Poveda, G.: Evidences of climate and environmental change on water resources and malaria in Colombia, IOP Conf. Series, Earth Environ. Sci., 6, 292054, doi:10.1088/1755-1307/6/9/292054, online available at: http://www.iop.org/EJ/toc/1755-1315/6/29, 2009.

Poveda, G. and Mesa, O. J.: Feedbacks between hydrological processes in tropical South America and large-scale oceanicatmospheric phenomena, J. Climate, 10, 2690-2702, 1997.

Poveda, G., Jaramillo, A., Gil, M. M., Quiceno, N., and Mantilla, R.: Seasonality in ENSO-related precipitation, river discharges, soil moisture, and vegetation index (NDVI) in Colombia, Water Resour. Res., 37(8), 2169-2178, 2001.
Poveda, G., Mesa, O. J., Salazar, L. F., Arias, P. A., Moreno, H. A., Vieira, S. C., Agudelo, P. A., Toro, V. G., and Alvarez, J. F.: The diurnal cycle of precipitation in the tropical Andes of Colombia, Mon. Weather Rev., 113, 228-240, 2005.

Poveda, G., Waylen, P. R., and Pulwarty, R.: Modern climate variability in northern South America and southern Mesoamerica, Palaeogeogr. Palaeocl., 234, 3-27, 2006.

Ramirez, E., Francou, B., Ribstein, P., Descloitres, M., Guerin, R., Mendoza, J., Gallaire, R., Pouyaud, B., and Jordan, E.: Small glaciers disappearing in the tropical Andes: a case study in Bolivia: Glaciar Chacaltaya (16 S), J. Glaciol., 47(157), 187-194, 2001.

Sidjak, R. and Wheate, R. W.: Glacier mapping of the Illecillewaet icefield, British Columbia, Canada, using Landsat TM and digital elevation data, Int. J. Remote Sens., 20(2), 273-284, 1999.

Silverio, W. and Jaquet, J. M.: Glacial cover mapping (1987-1996) of the Cordillera Blanca (Perú) using satellite imagery, Remote Sens. Environ., 95(3), 342-350, 2005.

Soruco, A., Vincent, C., Francou, B., and Gonzalez, F. J.: Glacier decline between 1963 and 2006 in the Cordillera Real, Bolivia, Geophys. Res. Lett., 36, L03502, doi:10.1029/2008GL036238, 2009.

van der Hammen, T.: The plio-pleistocene climatic record of the tropical Andes, J. Geol. Soc. London, 142, 483-489, 1985.

Vuille, M., Francou, B., Wagnon, P., Juen, I., Kaser, G., Mark, B. G., and Bradley, R. S.: Climate change and tropical Andean glaciers: Past, present and future, Earth-Sci. Rev., 89, 79-96, 2008.

Waylen, P. R. and Poveda, G.: El Niño-Southern Oscillation and aspects of western South American hydro-climatology, Hydrol. Process., 16(6), 1247-1260, 2001. 